\title{
PRAVNA PRIRODA MERE ODUZIMANJA IMOVINE PROISTEKLE IZ KRIVIČNOG DELA
}

\author{
Jelena Gluščević \\ Univerzitet Privredna akademija, Fakultet savremenih umetnosti, Beograd \\ Dragan Radoman \\ Bogoslovija Svetog Petra Cetinjskog, Cetinje
}

\begin{abstract}
$\mathrm{M}$ era oduzimanja imovine proistekle iz krivičnog dela uvedena je posebnim zakonom i njena primena je propraćena normativnom i institucionalnom podrškom kao obezbeđenje njenog opstajanja u savremenom sistemu krivičnih mera i sankcija. Bez obzira na sada već višegodišnju primenu posebne mere, neopravdano je izostala ozbiljnija i obimnija teorijsko-pravna argumentacija njenih suštinskih karakteristika, njenog mesta u okviru krivičnopravnog sistema, kao i pitanja njene pravne prirode. Cilj rada jeste da pruži odgovor na pitanje njene pravne prirode, adekvatnu argumentaciju za takav odgovor, a koja ujedno opisuje njene suštinske karakteristike. Takvim prikazom nastoji se s jedne strane otklanjanju nedoumice koje su kod postojanja i primene posebne mere prisutne, kako zbog terminoloških zabuna, tako i zbog nedovoljne istraženosti njenih specifičnosti, a sa druge određivanju mesta koje joj, bez obzira na to što nije obuhvaćena odredbama KZ-a, njoj nesporno, ali i de facto pripada.
\end{abstract}

Ključne reči: mera oduzimanja imovine proistekle iz krivičnog dela, konfiskacija imovine, pravna priroda, krivične sankcije i mere, sui generis

\section{Uvodna razmatranja}

U nizu problema koji prate neminovnu i stalnu modernizaciju i progres društva prisutne u velikom broju savremenih država, pa i u našoj, javlja se i pojava novih vidova kriminala za koje tradicionalna krivičnopravna nauka nije imala adekvatno rešenje, a među kojima se kao najopasniji i najrazorniji ističe problem pojave organizovanog kriminala. Kao jedan od koraka koje je Srbija preduzela da bi izgradila adekvatan sistem kojim bi suzbila ili bar kontrolisala narasli stepen kriminaliteta, pre svega organizovanog, bio je donošenje posebnog zakona kojim se uvodi nova mera krivičnog prava, mera oduzimanja imovine proistekle iz krivičnog dela. Dva su ključna elementa sjedinjena u ovoj meri; prvi, njena sposobnost da "slomi" konglomerat moći skoncentrisan u rukama čelnika kriminalnih grupa i da razori njihov imovinski oslonac i drugi, nastojanje da se njome obezbedi "imovinska pravda" koja je narušena sticanjem imovine kriminalnog porekla, kroz ostvarenje principa krivičnog prava da se niko ne može obogatiti vršenjem krivičnih dela. Narodna skupština RS je 23. oktobra 2008. godine donela Zakon o oduzimanju imovine proistekle iz krivičnog dela ${ }^{1}$ (u daljem tekstu Zakon) koji

\footnotetext{
1 “Službeni glasnik RS“, broj 97/2008.
} 
je stupio na pravnu snagu 1. marta 2009. godine i kojim se u naš pravni sistem uvodi posebna mera krivičnog prava. Nakon skoro petogodišnje primene Zakona, sa namerom da se unapredi primena mere oduzimanja imovine proistekle iz krivičnog dela, donet je novi Zakon ${ }^{2}$ istog naziva, kojim se u odnosu na prvobitno donet zakon uvode izvesne novine upravljene na njegovo poboljšanje. Ozbiljnost i rešenost države da se na ovaj način rešavaju problemi naraslog kriminaliteta pokazuje činjenica da je nova mera podržana specijalnom zakonskom regulativom (lex specialis za njenu primenu) kao i institucionalnom podrškom koja je podrazumevala osnivanje posebnih organa sa nadležnostima usmerenim na njenu primenu. ${ }^{3}$ lako je praktična primena mere i njena efikasnost upravo ono čime se vrednuje uspešnost odluke da se izgradi novi metod za sprečavanje kriminalnog bogaćenja, teorijska razrešenja pojedinih nedoumica u formiranju ovog sistema uvek su poželjna.

Mera oduzimanja imovine proistekle iz krivičnog dela je relativno nova u našem pravu, te takvo stanje prema kome njena primena nije propraćena značajnijim teorijskim razmatranjima nje same, a ni njene pravne prirode nije neuobičajeno. Ona se primenjuje od njenog uvođenja, ali stiče se utisak (bez obzira na nespornost njene primene i delovanja, i bez obzira na diskutabilnost više činilaca koji istu prate) da su pitanja od važnosti za nju ostavljena po strani.

Možemo ustanoviti da je odsustvo ozbiljnije naučne argumentacije o ovoj temi neopravdano, a nastalo je zbog jednim delom nepoznavanja njenih suštinskih karakteristika, kao i nepoverenja u njen opstanak kao modernog instituta krivičnog prava. Verujući u to da će ona i njena primena biti nužan deo modernog krivičnog prava i da će njena izvesna „elastičnost“ u poštovanju nekih od tradicionalnih načela krivičnog prava za pravnu teoriju domaćeg prava morati postati prihvatljiva, određenje njene pravne prirode smatramo izuzetno značajnim, i teorijski i praktično. Određenje pravne prirode mere oduzimanja imovine proistekle iz krivičnog dela, važno je, jer se ona kao mera, zbog specifičnosti koje poseduje, izdvaja u poseban institut krivičnog prava. Ona se zbog svojih karakteristika i pravne prirode, kao i zbog posebnog postupka u kome se sprovodi, jasno odvaja od svih postojećih krivičnopravnih mera i sankcija. Da bismo utvrdili pravnu prirodu mere oduzimanja imovine moramo pružiti analizu nekoliko važnih segmenata posebne mere, koji će skupno biti elementi definicije pravne prirode. Važno je ispitati nekoliko važnih stvari za definisanje pravne prirode posebne mere. Prvo ispitati njeno mesto u postojećoj sistematici mera i krivičnih sankcija domaćeg prava i koje su mogućnosti za njenu pripadnost nekoj od postojećih grupa. U isto vreme potrebno je naglasiti neprihvatljivost njenog poistovećivanja sa nekima od mera i sankcija sa kojima ima sličnosti. Ujedno, važno je ispitati postojeće stavove domaćih autora o njenoj pravnoj prirodi, o načinu na koji se opredeljuje pravna priroda i pravnoj prirodi mera sličnih njoj u domaćem ali i inostranom pravu. Na kraju, možda i najvažnije za opredeljenje stava o pravnoj prirodi jeste ispitivanje svih relevantnih karakteristika koje posebna mera ima, čime se, naposletku, na najbolji način određuje suština same mere.

\footnotetext{
2 "Službeni glasnik RS", broj 32/2013, 94/2016.

${ }^{3}$ Gluščević, J. (2016): „Upravljanje imovinom kriminalnog porekla i glavni uzročnici nedovoljne efikasnosti sistema upravljanja“, Ekonomika, Niš, 144.
} 


\section{Mesto mere oduzimanja imovine proistekle iz krivičnog dela u postojećem sistemu krivičnih sankcija i mera}

Da bismo odredili pripadnost posebne mere u sistemu krivičnopravnih mera i sankcija u našem pravu, moramo pružiti analizu ključnih karakteristika postojećih podela i ispitati da li mera oduzimanja imovine poseduje karakteristike koje bi je svrstale u neku od njih. Često su prisutna poistevećivanja mere oduzimanja imovine sa kaznom konfiskacije imovine, koja više nije deo važećeg prava (sa njom zbog terminološke sličnosti najviše, ali i zbog činjenice da se vrši oduzimanje imovine bez jasne povezanosti sa konkretnim krivičnim delom) i merom oduzimanja imovinske koristi (najviše zbog cilja na koji su obe upravljene). Isto tako, u određenim periodima naše pravo poznavalo je rešenja slična posebnoj meri kojima se nastojalo vršiti preispitivanje porekla imovine u nameri oduzimanja one koja je stečena nezakonito. Ipak određenjem pravne prirode nove mere ukazuje se na najjasniji način zbog čega poistovećivanju, sa bilo kojom od mera koje postoje ili su postojale, nema mesta. Često ćemo naići na pojam konfiskacije imovine u stranoj literaturi, za određenje mere koja je po suštini bliža novoj meri nego kazni konfiskacije imovine koja je u našem pravu nekada postojala. Upotreba tog termina ne treba da dovodi u zabunu, jer ovaj termin pokriva mnoge modalitete oduzimanja imovine, te terminološka istovetnost u ovom slučaju ne znači i suštinsku. Koji termin će biti upotrebljen za novu meru manje je važno, ukoliko je njena suština jasna. Iz tog razloga mora se dublje istražiti šta karakteriše meru oduzimanja imovine ali i ostale mere i sankcije sa sličnim nazivom ili ciljem, da bi se mogla podvući jasna razlika između njih. Najpre, karakteristike koje poseduje posebna mera najlakše ćemo utvrditi njenim upoređivanjem sa postojećim sličnim merama i sankcijama krivičnog prava i istraživanjem mogućnosti svrstavanja nje u postojeću sistematiku krivičnog prava, te istraživanjem mogućnosti pripajanja nje drugim merama i uvrstavanja u postojeći sistem krivičnih mera i sankcija. Time postižemo izdvajanje njenih ključnih karakteristika.

Određivanje mesta u postojećem sistemu i definisanje u Krivičnom zakoniku delimično daje odgovor o pravnoj prirodi svakog instituta. Ipak opredeljenje zakonodavca za mesto određene mere u okviru sistematike ne sme biti ključno za određenje pravne prirode naročito jer je ono podložno promenama i zna biti izraz stava aktuelnog zakonodavca. Kako Kambovski ${ }^{4}$ ističe, „za razliku od opštih instituta kaznenog prava, kod kojih je postignut visok stepen unifikacije i harmonizacije, u nacionalnim sistemima kazni postoje i danas velike razlike, ne samo u sistematizaciji određene sankcije, kazne ili druge sankcije, nego i unutar sistema kazni: još su brojna zakonodavstva koja predviđaju smrtnu kaznu, kazna zatvora ima različita trajanja, neka zakonodavstva ne poznaju kaznu zatvora doživotnog trajanja, u nekim zakonodavstvima u sistem kazni uključene su sporedne kazne zasnovane na gubitku opredeljenih prava itd“. Za pravilno određenje pravne prirode neke mere mnogo je značajnije poznavanje njenih suštinskih karakteristika jer takvo utemeljenje opstaje bez obzira na aktuelnosti koje utiču na zakonsku sistematiku. Ipak da bismo imali prava saznanja o pojedinom institutu koji analiziramo ne možemo ga posmatrati ni izolovano od socioloških i drugih faktora koji ga takođe određuju. „Bilo da je pretežno represivna ili preventivna, stroga ili humana

\footnotetext{
${ }^{4}$ Kambovski, V. (2006): Kazneno pravo opšt del, Skoplje, 653.
} 
orijentacija zakonodavca u definisanju celokupne kriminalne politike, koja treba da omogući vidove kazne kao način za njeno ostvarenje, profilisanje sistema je determinisano i drugim faktorima: tradicijom, institucionalnim, materijalnim i drugim mogućnostima države za primenu određenog vida kazne, podrškom ili neprihvatanjem određene kazne od strane javnosti itd“. ${ }^{5}$ Mera oduzimanja imovine je u našem pravu uređena posebnim Zakonom. U njemu se ne govori o položaju, niti o pravnoj prirodi mere, već samo o posebnom postupku u kom se ona izriče. Mera oduzimanja imovine nije regulisana Krivičnim zakonikom kojim je predviđen sistem krivičnih sankcija i drugih mera, niti je na bilo koji drugi način rešeno pitanje da li je u pitanju nova mera krivičnog prava ili samo proširena primena već postojeće mere. Kako primećuje Trešnjev ${ }^{6}$ „pojavljuje se nedoumica da li je intencija zakonodavca bila da oduzimanje imovine proistekle iz krivičnog dela definiše kao procesnopravni institut ili kao krivičnopravni institut sa procesnim odredbama koje ga neminovno prate." Svrstavanje mere oduzimanja imovine u sistem krivičnih mera i sankcija i njeno određenje u okviru Krivičnog zakonika bilo bi značajno jer bi se na taj način otklonile brojne nedoumice, a ujedno bi ona kao mera bila mnogo manje podložna izmenama i eventualnim pokušajima njenog ukidanja. Ipak ovo pitanje nije jednostavno jer ona prema svojim karakteristikama ne nalazi svoje mesto ni u jednoj od postojećih podela krivičnih mera i sankcija, a kada bi joj ono i pripalo, ona bi u odnosu na njih pokazivala određena odstupanja. S druge strane, prosto prihvatanje ove mere kao sui generis mere, dakle nepripadajuće, odnosno posebne po svojim karakteristikama, nije samo po sebi dovoljno da bi se problem njene pripadnosti rešio.

U sistemu krivičnih sankcija u našem pravu, nalaze se četiri vrste krivičnih sankcija: kazne, mere upozorenja, mere bezbednosti i vaspitne mere. Ujedno, postoje mere koje se ne nalaze u sistemu krivičnih sankcija, jer ne poseduju osnovne elemente krivičnih sankcija, ali su im veoma slične. U razmatranju problema koji je pred nama, najpre moramo ispitati praksu drugih zemalja koje su usvojile slične mere. Usvajanje ovakvih iskustava mora biti uvek sa zadrškom jer svaka zemlja ima osoben krivičnopravni sistem, prilagođen sopstvenim potrebama, pa je uvek neophodna šira analiza celog sistema propisa, a ne samo mere o kojoj govorimo. Stavovi o pravnoj prirodi oduzimanja imovine proistekle iz krivičnog dela u uporednom pravu su različiti, pre svega zbog velikih razlika u samim pravnim sistemima, različitim okolnostima i periodima u kojima je nastala ova mera, kao i vrsti postupka koji je predviđen za oduzimanje imovine. Sličnosti su veće među onim zemljama koje meru oduzimanja imovine sprovode u istoj vrsti postupka, te kada je o našem pravu reč, slična rešenja imaju zemlje kontinentalnog prava koje oduzimanje imovine sprovode u okviru krivičnog postupka ili paralelno sa njim. Veliki uticaj na kvalifikovanje mere oduzimanja imovine proistekle iz krivičnog dela imaju određeni međunarodni dokumenti koji se ovim pitanjem bave, a pre svih ističemo uticaj stava koji zauzima Evropski sud za ljudska prava po ovom pitanju. Međunarodni dokumenti dopuštaju da to bude kazna ili mera koju izriče sud po sprovedenom postupku u vezi sa jednim ili više krivičnih dela, kojom se pravnosnažno oduzima imovina. ${ }^{7}$ Strazburška i Varšavska konvencija, su među najznačajnijim međunarodnim do-

\footnotetext{
${ }^{5}$ Kambovski , V., 653.

${ }^{6}$ Trešnjev, A. (2008): „O radnoj verziji Nacrta Zakona o oduzimanju imovine proistekle iz krivičnog dela“, Revija za bezbednost, Beograd, 21.

${ }^{7}$ Ilić, G., Majić, M., Nikolić, B., Melilo, Đ. (2009): Komentar Zakona o oduzimanju imovine proistekle iz krivičnog dela, Misija OEBS, Beograd, 56.
} 
kumentima koja se bave ovim pitanjima, i one u svom tekstu daju određenje pojma konfiskacije. U svakom slučaju ukoliko one nisu kategorisane prema domaćim propisima, procenjuju se njihove karakteristike u svakom konkretnom slučaju.

Sledeći korak na putu određenja pravne prirode posebne mere jeste izdvajanje karakteristika koje je ključno približavaju ili udaljavaju od postojećih mera i sankcija krivičnog prava i uključuju ili isključuju iz postojeće sistematike krivičnog prava. Neretko ćemo naići na shvatanja o meri oduzimanja imovine kao kazne, bilo da se poistovećuje sa nekadašnjom kaznom konfiskacije imovine, bilo da se ona ocenjuje kao izrazito represivna, zbog čega joj se pridaje kazneni karakter. Takva shvatanja ne mogu biti prihvaćena, a razlozi za to postaju jasni ukoliko se mera oduzimanja imovine suštinski razume. Opšta svrha krivičnih sankcija ${ }^{8}$ se ogleda u suzbijanju dela kojima se povređuju ili ugrožavaju vrednosti zaštićene krivičnim zakonodavstvom, sprečavanju učinioca da čini krivična dela, zatim uticanju na njega da ubuduće ne čini krivična dela, uticajem na druge da ne čine krivična dela, izražavanju društvene osude za krivično delo, jačanju morala i učvršćivanju obaveze poštovanja zakona. Svrha kažnjavanja u našem krivičnom pravu određena je kroz dva osnovna cilja: delovanje na učinioca da ne ponovi kriminalno ponašanje (specijalna prevencija) i uticaj na građane da se uzdrže od vršenja krivičnih dela (generalna prevencija $)^{9}$. Mera oduzimanja imovine nije po svom karakteru kaznena, iako u primeni može imati određena obeležja kazne, pa se ne može govoriti o njenoj pripadnosti kaznama. Kod oduzimanja imovine, iako je krivica uslov koji redovno prati postupak oduzimanja imovine, akcenat ipak nije na učiniocu nego na samoj imovini, jer se dokazuje njeno nezakonito poreklo. Krivica za izvršenje krivičnog dela nije predmet posebnog postupka, niti ona mora postojati kod oduzimanja imovine, ona je samo inicijalni pokretač posebnog postupka. Za razliku od kazne gde se redovno radi o subjektiviziranoj krivici, dejstvo mere oduzimanja imovine proteže se i na lica koja nisu okrivljena nego su pravni sledbenici, naslednici okrivljenog ili treća lica. Sud dalje, kod izricanja kazne uzima u obzir olakšavajuće i otežavajuće okolnosti koje mogu uticati na njeno odmeravanje, dok kod izricanja mere oduzimanja imovine jedino što utiče na odmeravanje visine iznosa koji se ima oduzeti jeste utvrđeni obim nezakonito stečene imovine. Za razliku od kazne, bez obzira na krivicu, stepen odgovornosti, pobude, imovinsko stanje učinioca i slično, do oduzimanja imovine nikada neće doći ukoliko se tokom postupka pokaže da je prevashodni deo imovine vlasnika „pokriven“ njegovim zakonitim prihodima. ${ }^{10}$ Iz svega iznetog, a bez obzira na stav ESLJP-a, bar kada je reč o našem zakonodavstvu, ne može se argumentovano potkrepiti stav da je oduzimanje imovine po svojoj prirodi kazna. Ona ima samo izvesne sličnosti sa kaznom, ali se u kazne ne može svrstati.

Svrstavanje mere oduzimanja imovine u mere bezbednosti otpada iz sličnih razloga zbog kojih je i mera oduzimanja koristi stavljena van ove podele. Naime, mere bezbednosti za svoj osnovni cilj imaju otklanjanje opasnosti od ponovnog vršenja krivičnog dela, dakle usmerene su na potencijalne učinioce. Mera oduzimanja takođe ostvaruje ovaj cilj, ali ne

\footnotetext{
${ }^{8}$ Član 4. stav 2. Krivičnog zakonika RS.

${ }^{9}$ Lazarević, Lj. (2006): Komentar Krivičnog Zakonika Republike Srbije, Beograd: Savremena administracija, 2006, 161.

${ }^{10}$ Majić, M. (2010): „Oduzimanje imovine proistekle iz krivičnog dela“, Bilten Apelacionog suda u Beogradu, Broj $\mathrm{l} / 2010$, Beograd, 49.
} 
kao osnovni i primaran. Naime, oduzimanjem kriminalnog profita izvršilac se onemogućava ili mu se otežava dalje vršenje krivičnih dela, jer je profit najčešće osnova za dalji razvoj kriminalne delatnosti. Takođe oduzimanjem imovine kriminalnog porekla onemogućavaju se i lica koja su povezana sa izvršiocem, da nastave kriminalnu delatnost ukoliko je on lišen slobode. Ipak ovu svrhu, mera oduzimanja imovine ostvaruje samo posredno. Dakle zaključujemo da mera oduzimanja imovine ostvaruje svrhu mera bezbednosti, ali isto kao i kod primera kazni, samo kao sporedan cilj, jer je njen osnovni cilj drugi.

Još jedna od mogućnosti koja se javlja kod rešavanja pitanja pripadnosti posebne mere jeste da se ona smatra pravnom posledicom osude. Pravne posledice osude ne pripadaju ni krivičnim sankcijama, niti ostalim merama o kojima sud odlučuje, nego nastupaju po sili zakona. One se sastoje u prestanku ili gubitku određenih prava ili zabrani sticanja određenih prava i nastupaju po sili zakona. Ono što je zajedničko njima i meri oduzimanja imovine jeste to da se izriču samo u slučajevima izvršenja težih krivičnih dela, odnosno izricanja težih krivičnih sankcija. Suštinsko obeležje posebne mere zapravo i jeste da automatski, osudom za neko od krivičnih dela koja su zakonom predviđena, naročito za krivično delo organizovanog kriminala čije je jedno od glavnih obeležja trajnija delatnost, nastupa pretpostavka da je osuđeni držalac imovine kriminalnog porekla. Međutim kod pravnih posledica osude radi se o gubitku određenih prava koje je okrivljeni imao dok se kod oduzimanja imovine oduzima imovina baš zbog toga što je ona u posedu okrivljenog ili trećeg lica bez pravnog osnova. Takođe, do oduzimanja imovine ne može doći automatski, njoj mora prethoditi dokazivanje porekla imovine, dok dejstva pravnih posledice osude nastupaju odmah po pravnosnažnosti presude. Šta više, pre bi se moglo razmišljati o svrstavanju mere oduzimanja imovinske koristi u ovu kategoriju, zbog činjenice da bi ona trebala da se obavezno izriče kao posledica izvršenja krivičnog dela i osude za njega, dok kod mere oduzimanja imovine osim iznetih sličnosti, nema osnova za to.

Ono što je jedna od bitnih karakteristika ove mere jeste i ostvarenje preventivne uloge, kako specijalne (koja je u prvom planu kod mera bezbednosti) tako i generalne prevencije (koja je osim prekora prema učiniocu osnovna svrha). Specijalna prevencija koja je izražena kod izricanja mere oduzimanja imovine ogleda se u činjenici da se učiniocu kome se oduzima celokupna imovina koja je plod kriminalnih aktivnosti stavlja do znanja da će eventualni propusti u krivičnom postupku koji su mu išli u prilog biti nadomešćeni, bar u imovinskom delu, u posebnom postupku. Činjenica da postoji opasnost da se celokupna imovina izvršioca nađe pod prismotrom i na kraju procesuira, u velikoj meri destimuliše izvršioca za izvršenje krivičnog dela, ili nastavak kriminalnih aktivnosti. S druge strane, generalna prevencija kod primene mere oduzimanja imovine je veoma izražena jer se destimulišu i potencijalni izvršioci krivičnih dela. U nameri izvršenja krivičnog dela, saznanje da će korist koju će izvršilac krivičnog dela steći biti oduzeta, ne vrši na njega isti pritisak kao činjenica da će vršenjem krivičnih dela dovesti u opasnost i imovinu koju je ranije nezakonito stekao. Njenom primenom daje se do znanja da se niko ne može bogatiti bavljenjem nezakonitim i kriminalnim delatnostima, a ta svrha se pojačava naročito uticajem medija koji postupke oduzimanja imovine smatraju uvek aktuelnim za izveštavanja. Obuhvaćena je znatno šira imovina koju je okrivljeni nelegalno stekao nego što je to slučaj sa bilo kojom do sada predviđenom merom, te takva opasnost predstavlja mnogo veći pritisak za njega, a rizik koji preuzima upuštajući se u bavljenje kriminalnim delatnostima znatno se povećava. Strah od primene ovakve jedne mere je intenzivniji i mnogo jače doprinosi generalnoj prevenciji, a u istoj liniji i specijalnoj prevenciji. 


\section{Diferenciranje posebne mere od mere oduzimanja imovinske koristi}

Drugi zadatak koji imamo, pre određenja pravne prirode mere, jeste pružanje argumenata kojima opravdavamo stav o samostalnosti mere oduzimanja imovine u odnosu na meru oduzimanja imovinske koristi, a time i samostalnosti u određenju pravne prirode posebne mere. Često zastupan stav u našoj krivičnopravnoj teoriji, naročito među autorima koji su među prvima izneli svoje mišljenje o ovoj temi, jeste taj da ćemo odgovor na pitanje pravne prirode mere oduzimanja imovine pronaći u već datom odgovoru o pravnoj prirodi mere oduzimanja imovinske koristi, pa se oni dalje i ne upuštaju u analizu njene pravne prirode Jedan značajan broj autora koji su se bavili ovom temom, priklonjeni su stanovištu da je oduzimanje imovine samo jedan vid oduzimanja imovinske koristi, te se stoga opredeljuju za istu pravnu prirodu koja je već ustanovljena za meru oduzimanja imovinske koristi ili se ne izjašnjavaju o pravnoj prirodi te mere zasebno. Možda i shvatanje o njihovoj sui generis pravnoj prirodi dodatno doprinosi zabludi o njihovoj istovetnosti. Nesumnjivo je da ove dve mere imaju dosta sličnosti, te da je i oduzimanje imovine usmereno na uspostavljanje imovinskog stanja koje je postojalo pre nego što je okrivljeni imovinu protivpravno pribavio, kao što to ima za cilj i mera oduzimanja imovinske koristi, ali dok je kod oduzimanja imovinske koristi to glavna svrha izricanja, kod oduzimanja imovine ostvaruju se i drugi efekti. Mera oduzimanja imovine svakako jeste produkt evoluiranja ideje o oduzimanju imovinske koristi, koja je modifikovana sa pojavom organizovanog kriminala, ali ona ima niz drugih posebnih karakteristika koje je izdvajaju kao posebnu meru. Dok se oduzimanje imovinske koristi izriče tek kada bude dokazana krivica okrivljenog, kod oduzimanja imovine samo podizanje optužnice omogućuje prvo njeno privremeno oduzimanje, zbog čega okrivljeni trpi posledice i pre osude. Nakon toga sledi oduzimanje celokupne imovine za koju okrivljeni ne dokaže zakonito poreklo, a ne samo imovine koja je stečena vršenjem konkretnog krivičnog dela. Kod oduzimanja imovinske koristi učinilac je najčešće unapred pomiren sa činjenicom da će stečenu imovinsku korist morati da vrati, jer je optužen za krivično delo iz kojeg je tu korist i ostvario. Kod oduzimanja imovine imamo udar na njegovu celokupnu imovinu, kao i na imovinu porodice njemu bliskih lica, te ova mera ima dalekosežnije posledice. Zato naglašavamo prisustvo kaznenog karaktera kod posebne mere, dok on nije prisutan kod mere oduzimanja imovinske koristi, naročito ne prema našim propisima, jer se pri utvrđivanju visine koristi koristi tzv. neto princip. U našem pravu se prilikom oduzimanja imovinske koristi pribavljene krivičnim delom sud rukovodi tzv. neto načelom, što znači da oduzima samo čistu dobit koju je učinilac krivičnog dela ostvario. ${ }^{11}$ Primenom tzv. neto načela nastoji se učiniocu oduzeti „čisto stečena dobit“, uz uračunavanje određenih troškova koje je imao pri izvršenju krivičnog dela. Kod nas sud primenjuje tzv. neto načelo pri određivanju visine imovinske koristi koju je izvršilac krivičnog dela stekao. Sa druge strane, prema sistemu u kome se primenjuje tzv. bruto načelo pri utvrđivanju visine ostvarene imovinske koristi, učiniocu se ne priznaju nikakvi troškovi, te mu se oduzima i veća vrednost od one koju je stvarno

\footnotetext{
${ }^{11}$ llić, G. i dr. (2009): Komentar Zakona o oduzimanju imovine proistekle iz krivičnog dela, Misija OEBS, Beograd, str. 56-60.
} 
stekao. Učiniocu se oduzima i onaj deo imovine (a koji čini ovu razliku) koji je zaista njegov, te se zato u tom slučaju ističe jači kazneni karakter mere. Na kraju one se izriču u dva drugačija postupka, primena jedne ne isključuje primenu druge što potvrđuje da svaka od njih ima svoju samostalnost.

\section{Postojeći naučni i stručni stavovi o pravnoj prirodi mere oduzimanja imovine}

Treće područje naše analize koja nas približava određenju pravne prirode nove mere jeste prikaz postojećih stavova domaćih autora, kao i autora sa prostora bivše Jugoslavije, ali i stava koji je izneo Ustavni sud, o njenoj pravnoj prirodi. Ilić iznosi stav da je „trajno oduzimanje imovine proistekle iz krivičnog dela mera sui generis", navodeći osobenosti koje ima, a koje je razlikuju od kazne. Podsećajući na represivni aspekt krivičnih sankcija, autor ističe princip na kome se zasniva oduzimanje imovine kao i oduzimanje imovinske koristi, te osporava represivni karakter mere oduzimanja imovine zbog nemogućnosti da se iz neprava stekne neko pravo. Primena te dve mere „dovodi do uspostavljanja imovinskog stanja koje je narušeno izvršenjem krivičnog dela, odnosno kriminalnom aktivnošću, pa se može govoriti o restorativnom karakteru ovih mera". ${ }^{12}$ Autor dalje upućuje na procesne razlike između kazne i oduzimanje imovine, razlike u samim postupcima u okviru kojih se odlučuje o primeni mera i na kraju razliku u obimu imovine koja se oduzima. Govoreći o obimu imovine on navodi da se "prilikom oduzimanja imovinske koristi pribavljene krivičnim delom sud rukovodi neto načelom, što znači da oduzima samo čistu dobit koju je učinilac krivičnog dela ostvario“ te ističe „nepunitivni karakter mere oduzimanja imovinske koristi“, a koji se da primeniti i na trajno oduzimanje imovine proistekle iz krivičnog dela. ${ }^{13}$ Drugačije shvatanje bi po njemu označavalo kažnjavanje vlasnika.

Ne sporivši da je određenje pravne prirode oduzimanja imovine kao mere sui generis najprihvatljivije, ipak smatramo da ne treba zanemariti u tom kvalifikovanju elemente kaznenog karaktera koje ima. Zapravo, tačno je da se oduzima samo onaj deo imovine koja prevazilazi zakonite prihode njenog vlasnika, ali samo stavljanje pod lupu celokupne imovine vlasnika i primena pravila o tzv. „obrnutom ili podeljenom“ teretu dokazivanja, jeste vid kazne za njenog imaoca. U redovnim krivičnim postupcima raspravlja se samo o glavnoj stvari povodom koje se postupak vodi, dok se kod pokretanja posebnog postupka raspravlja o celokupnoj imovini okrivljenog, pa čak i onoj koju je preneo na druga lica. Ulog je mnogo veći, obim zahvatanja imovine mnogo širi, a posledica primene ovakve mere uvek predstavlja najveću kaznu za njene učinioce.

Ilić praveći paralelu između trajnog oduzimanja kriminalne imovine i oduzimanja imovinske koristi, dalje zaključuje „da se obe zasnivaju na ideji pravičnosti, uspostavljanju prethodnog imovinskog stanja, da imaju restorativni karakter, da rade na specijalnoj i generalnoj prevenciji, a kao razliku navodi to što se trajno oduzimanje kriminalne imovine sprovodi na celokupnoj imovini (koja se pokaže nezakonito stečenom), a kod oduzimanja

\footnotetext{
12 Ibid.

${ }^{13}$ Ilić G. i dr., 14-15.
} 
imovinske koristi reč je o imovini koja je u vezi sa određenim krivičnim delom“. Tomić analizirajući specifični karakter oduzimanja imovinske koristi, a te specifičnosti se u najmanju ruku mogu pripisati i meri oduzimanja imovine, govori da ona „iako nije krivična sankcija, na svoj način doprinosi ostvarivanju iste svrhe koje imaju i krivične sankcije, tj. deluje u pravcu suzbijanja društveno opasnih delatnosti kojima se povređuju ili ugrožavaju društvene vrednosti zaštićene krivičnim zakonodavstvom" te da ova mera deluje "kako na planu specijalne tako i na planu generalne prevencije". ${ }^{14}$ Ignjatović deli stav većine naših pravnih teoretičara i praktičara o svrstavanju trajnog oduzimanja imovine u mere sui generis, koristeći mere oduzimanja imovine i imovinske koristi u svojim stavovima kao sinonime. Na taj način on meri oduzimanja imovine ne priznaje samostalnost. Autor dalje naglašava imovinsko-pravni karakter mere i i njenu in rem prirodu, te „da ona nema kazneni karakter već se odlikuje preventivnim karakterom“" ${ }^{15}$. Njen imovinsko-pravni karakter je nesporan, ali smatramo da je ona ipak u našem pravnom sistemu prevashodno uperena protiv lica, a ne protiv imovine, bar ne nezavisno od samog učinioca, jer pokretanje postupka o oduzimanju imovine ne može uslediti bez postojanja krivičnog postupka, dakle bez osnovane sumnje o krivici učinioca. Ivičević Karas iako zastupa stav o in rem prirodi oduzimanja imovine (termin koji se koristi u hrvatskom pravu je oduzimanje imovinske koristi ostvarene kaznenim delom) ispravno uočava da se "ne može ustrajati na posebnoj restorativnoj prirodi tog oblika mere, jer prošireno oduzimanje imovinske koristi, s obzirom na svoje temeljne karakteristike, prema počinitelju u biti ima kazneni karakter“. ${ }^{16}$ Vrhovšek prethodno analizirajući stanje u ovoj oblasti u našem pravnom sistemu zaključuje „da trajno oduzimanje imovine proistekle iz krivičnog dela ne gubi, činjenicom da ista obuhvata celokupnu imovinu vlasnika, karakter sui generis mere koja se odlikuje restorativnom prirodom“, te da se radi o meri „preventivnog karaktera, a ne kaznenog“. ${ }^{17}$ Na znatno drugačiji stav o pitanju pravne prirode mere oduzimanja imovine nalazimo u radovima sudije Majića koji tvrdi da je ovde zapravo reč o posebnim pravilima o dokazivanju činjenice o kriminalnom poreklu imovine, te da ako ih shvatimo tako, kao procesna pravila, izbeći ćemo mnoge dileme vezane za ovo pitanje. Autor navodi da se „često u razmatranju pravne prirode ovog instituta, prenebregava činjenica da savremena procesna prava neretko predviđaju posebna pravila dokazivanja posebnih činjenica“ kao i da "savremena procesna prava poznaju čitav niz takozvanih pravnih pretpostavki“ te da je zapravo ovde „reč o posebnim pravilima dokazivanja činjenice saglasno kojoj je određena imovina pribavljena krivičnim delom“. ${ }^{18}$

Ovakvi stavovi smatramo ne opisuju pravnu prirodu mere oduzimanja imovine na pravi način, naročito ne u potpunosti. Zastupajući takav stav, po nama, opisuje se samo

\footnotetext{
${ }^{14}$ Tomić, Z. (1983): Pravna priroda mjere oduzimanja imovinske koristi pribavljene krivičnim delom, Godišnjak Pravnog fakulteta u Sarajevu, Sarajevo, 147.

${ }^{15}$ Ignjatović, A. (2010): Zakon o oduzimanju imovine proistekle iz krivičnog dela, sa osvrtom na izmene Zakona o krivičnom postupku, Pravo Teorija i praksa, Beograd, 196.

${ }^{16}$ Ivičević Karas, E. (2011): Komentar Zakona o postupku oduzimanja imovinske koristi ostvarene kaznenim djelom i prekršajem, Zagreb, 6-8.

${ }^{17}$ Vrhovšek, M. (2011): Šta još treba znati o oduzimanju imovine proistekle iz krivičnog dela, Sudska praksa: jugoslovensko stručno informativni časopis, br. 1/2, Beograd, 58.

${ }^{18}$ Majić, M. (2010): Oduzimanje imovine proistekle iz krivičnog dela, Bilten Apelacionog suda u Beogradu, Broj I/2010, Beograd, 45-51.
} 
jedan segment mere oduzimanja imovine, i to onaj procesni. Nesporno je da su u vezi sa postupkom oduzimanja imovine prisutna posebna pravila dokazivanja koja se na ovaj postupak odnose, ali se ona ne mogu poistovetiti sa suštinom oduzimanja imovine, a još manje se oduzimanje imovine kao krivičnopravna mera i njena pravna priroda mogu sadržati u ovakvom procesnom pravilu, već upravo obrnuto. Pravila dokazivanja samo su neodvojivi deo efikasnog funkcionisanja ovako osmišljenog načina oduzimanja imovine, donose određene specifičnosti u primeni te mere, a koje nisu svojstvene drugim sličnim merama. Stav autora da se ovakvim kvalifikovanjem mere mogu izbeći problemi (poput onog o nedozvoljenoj retroaktivnosti zakona) nije dovoljan argument da odustanemo od pronalaženja odgovora na pitanje njene pravne prirode. Škulić ${ }^{19}$ ne analizirajući detaljnije pitanje pravne prirode oduzimanja imovine, navodi da oduzimanje imovine nije krivična sankcija, ali da "ne može biti sporno da su odredbe tog zakona odgovarajuća mešavina odredbi krivičnog materijalnog i krivičnog procesnog prava, pri čemu samo trajno oduzimanje imovinske koristi do kojeg dolazi pod određenim uslovima, po svemu sudeći ima karakter mere koja je materijalnog krivičnog karaktera, bez obzira na to što formalno nije regulisana odredbama Krivičnog zakonika koji je naš osnovni izvor krivičnog materijalnog prava“. Autor navodi da se „termin konfiskacija u međunarodnim pravnim aktima sa stanovišta našeg pozitivnog krivičnog prava može shvatiti ili kao posebna vrsta kazne ili kao mera bezbednosti oduzimanja imovinske koristi“. ${ }^{20}$ Po stavu autora "formalno posmatrano uopšte se ni ne radi o "kriminalnoj" imovini jer je kriminalan samo onaj deo imovine za koji je pravnosnažno dokazano da je proistekao iz krivičnog dela“. ${ }^{21}$ Najpre, tačno je da se imovina koja se oduzima po Zakonu oduzima po principu ispitivanja porekla celokupne imovine okrivljenog, a ne samo imovine koja je vezana za konkretno krivično delo. Ovako stečena imovina čija nezakonitost proizilazi iz konkretnog krivičnog dela, ukoliko bi sudije postupale efikasno i pravilno, bila bi oduzeta izricanjem mere oduzimanja imovinske koristi u redovno sprovedenom krivičnom postupku. S druge strane, ukoliko bismo meru oduzimanja imovine, uz primenu tzv. obrnutog tereta dokazivanja, koristili za redovne krivične postupke, imali bismo problem sa nesrazmernošću mere koja se izriče, naspram dobara koja se povređuju, što bi dovelo do najgrubljeg kršenja ljudskih prava. Imovina koja se oduzima na ovaj način svakako jeste kriminalna, samo se dokazivanje o njenom kriminalnom poreklu sprovodi na drugačiji način, što dokazuje i to da je ipak uslovljena donošenjem odluke o krivici. lako se ne utvrđuje tačan bilans između učinjenih dela i vrednosti imovine, najčešće je jasno da ovakva imovina nije mogla biti stečena na drugi način osim kriminalom.

Za razliku od krivičnih sankcija čija je zajednička osnova ograničenje sloboda i prava izvršioca krivičnog dela, konfiskacija imovine, imovinske koristi i oduzimanja predmeta kao posebne kaznenopravne mere su pravna posledica samog dela, koje se ne vezuje za primenu sankcije. ${ }^{22}$ Različiti propisi važe u makedonskom pravu od onih u našem, pa

\footnotetext{
${ }^{19}$ Škulić, M. (2010): Organizovani kriminalitet, Beograd: Pravni fakultet Univerziteta u Beogradu, Beograd, 327.

20 Škulić, M. 327.

${ }^{21}$ Škulić, M. (2010): Kratki komentar osnovnih modifikacija krivičnog procesnog prava Srbije - izmene i dopune Zakonika o krivičnom postupku, odredbe Zakona o međunarodnoj pravnoj pomoći u krivičnim stvarima i odredbe Zakona o oduzimanju imovine proistekle iz krivičnog dela, Pravni portal, Smederevo, 103.

${ }^{22}$ Kambovski, V. (2006): Kazneno pravo opšti deo, Skoplje, 759.
} 
opredeljenje Kambovskog o pravnoj prirodi mera možemo uzeti samo uslovno za razmatranje pravne prirode posebne mere, jer je način oduzimanja imovine potpuno drugačiji. Ipak pristup definisanju pravne prirode ovih mera navedenog autora je značajan, jer objašnjava da ne može biti pravo rešenje da se pojedine mere shvate kao specifični oblici postojećih podela, jer bi takvo postupanje prouzrokovalo probleme. Kambovski dalje ističe «da za krivično pravo važi sledeće pravilo: pravna priroda ne može da bude polovična ili mešovita, tako da nijedna pravna posledica krivičnog dela ne može imati tri različita svojstva“. ${ }^{23}$ Posmatranje posebne mere kao pravne posledice krivičnog dela ima smisla, ali takvo opredeljenje na isti način kao i njeno opredeljene kao sui generis mere, ne smatramo kompletnim. Pitanje pravne prirode mere oduzimanja imovine se razmatralo i prilikom donošenja odluke Ustavnog suda ${ }^{24}$ o zahtevu za ocenu ustavnosti i/ili zakonitosti osporenog Zakona. Do tumačenja je došlo zbog nužnosti odgovora na pitanje retroaktivnosti Zakona i primene mere, a koje je nužno uslovilo i rešavanje pitanja pravne prirode mere. Ako bismo meru oduzimanja imovine, svrstali u krivične sankcije, onda bi se ona svela na lišavanje ili ograničavanje slobode ili prava lica prema kome se primenjuje. U donetoj odluci Ustavnog suda kazna se shvata kao institut koji „prati“ učinioca krivičnog dela, a mera oduzimanja imovine proistekle iz krivičnog dela kao mera koja "prati" nezakonito stečenu imovinu. Dalje, iznose se značajne razlike koje postoje između kazne i trajnog oduzimanja imovine, a tiču se okolnosti koje se uzimaju u obzir prilikom njihovog izricanja. Kod trajnog oduzimanja sud ne uzima u obzir stepen krivične odgovornosti niti pobude iz kojih je krivično delo učinjeno, imovinske prilike učinioca, jačinu ugrožavanja ili povrede zaštićenog dobra niti olakšavajuće okolnosti. U procesnom smislu, razlike su u tome što odluku o krivici prati uvek odluka o kazni, dok se odluka o trajnom oduzimanju imovine donosi u posebnom postupku, što znači da odluku o krivici ne prati nužno odluka o trajnom oduzimanju imovine.

Iz svega iznetog, trajno oduzimanje imovine proistekle iz krivičnog dela određuje se kao mera sui generis, koja se ne primenjuje ad personam, već in rem. Pravila kojima se uređuje oduzimanje imovine proistekle iz krivičnog dela u suštini su posebna pravila o dokazivanju činjenice o kriminalnom poreklu imovine. Još jednom je Ustavni sud potvrdio izneto mišljenje u Rešenju IUZ-117/2009 gde je zauzet pravni stav da bi se pitanje povratnog dejstva Zakona kao sporno moglo postaviti samo u slučaju da je trajno oduzimanje imovine po svojoj prirodi vrsta kazne. Po oceni Ustavnog suda ne radi se o kazni već o posebnoj meri koja se primenjuje na nezakonito stečenu imovinu, te se ustavna jemstva o zabrani retroaktivnosti ne mogu dovesti u vezu sa merom oduzimanja imovine. U pomenutim odlukama Ustavnog suda možemo naći smernice za određenje pravne prirode mere oduzimanja imovine. Međutim, izneti stavovi su više imali za cilj da otklone dileme u vezi sa retroaktivnom primenom Zakona, nego da se njima razjasni pravna priroda mere o kojoj govorimo. Odluka Suda predstavlja primer procene pravne prirode mere na osnovu njenog mesta, svrhe i postupka u kom se izriče u domaćem pravu, a u skladu sa preporukom ESLJP-a. Iz tog razloga donete odluke, treba uzeti kao smernicu, ali ne i kao konačni zaključak o pitanju pravne prirode mere oduzimanja imovine.

\footnotetext{
${ }^{23}$ Kambovski, V. 759.

${ }^{24}$ Ustavni sud Republike Srbije, luz-117/2009 od 30.06.2011. i luz-1632/2010 od 23.05.2012. godine.
} 


\section{Određenje pravne prirode mere oduzimanja imovine}

$\mathrm{Na}$ kraju analiza svih segmenata bitnih za određenje pravne prirode mere oduzimanja imovine vodi nas zaključku da je priroda mere polivalentna. Prema stavu koji zastupamo ona je potpuno nova mera, koja korene vuče iz nekih od poznatih mera krivičnog prava, ali ona je tvorevina Zakona i deo je celokupne sistemske podrške koja prati njenu primenu. Uvođenje novih mera u postojeći sistem krivičnog prava posebnim zakonima nije uobičajeno, jer su sankcije i srodne mere krivičnog prava regulisane odredbama Krivičnog zakonika. Ako se ovakvo odstupanje moglo opravdati time da je reč o potpuno novoj krivičnopravnoj meri, te da je bilo potrebno određeno vreme da se ispita efikasnost koju mera oduzimanja imovine ostvaruje, sada je vreme da se njen položaj učvrsti, njenim regulisanjem u Krivičnom zakoniku. S obzirom na to da ona, zbog karakteristika koje ima, ne može zauzeti mesto u postojećoj sistematici krivičnih mera i sankcija (osim u slučaju da bude izuzetak u odnosu na vrstu sankcije ili mere kojoj bi pripala), njoj pripada mesto u okviru posebne glave Krivičnog zakonika, kao mere sui generis. Ona bi mogla biti pripojena uz meru oduzimanja imovinske koristi kao njen specifičan oblik, ali bi takvo pripajanje bilo usiljeno i ne bi odražavalo njenu pravu pravnu prirodu.

Meri oduzimanja imovine pripada samostalno mesto u okviru posebnih mera krivičnog prava. Ona je posebna (sui generis, ${ }^{25}$ ) krivičnopravna mera, potpuno izdvojena, samostalna i jedinstvena po kompleksnosti karakteristika koje u sebi sadrži, od mera koje su do sada bile deo našeg pravnog sistema, koja ima restituciju kao osnovni cilj, ali sa izraženim dejstvima specijalne i generalne prevencije koju ostvaruje i sa prisutnom dozom kaznenog karaktera. Bez obzira na to što Zakon detaljno reguliše sva pitanja vezana za primenu mere oduzimanja imovine, njeno svrstavanje među krivične sankcije i mere koje su regulisane Krivičnim zakonikom je nužno, jer bi joj takav položaj obezbedio sigurnost postojanja, tim položajem bi se rešilo i pitanje njene pravne prirode, a što je najvažnije obezbedila bi se nedvosmislenost razlikovanja između mere oduzimanja imovine i ostalih mera krivičnog prava. Pitanje pravne prirode mere oduzimanja imovine je važno i zbog toga jer se rešavanjem tog pitanja rešava i pitanje da li je dozvoljena retroaktivna primena te mere, mada je to pitanje bilo aktuelno u početku donošenja propisa koji se na nju odnose. Bilo da je mera oduzimanja imovine samostalna krivičnopravna mera ili da se svodi samo na prošireno oduzimanje imovinske koristi, ono što je najbitnije jeste efekat koji će njena primena imati u celokupnoj borbi protiv najtežih oblika kriminala. Potrebno je, imajući u vidu sadržinu svih pomenutih ustanova krivičnog i građanskog prava i problematiku koja je pratila primenu svake od njih, odabrati najbolja rešenja iz iskustava koja smo imali. Trebalo bi zaobići sva ona problematična mesta u primeni krivičnih sankcija i mera, predvideti jasna razgraničenja oduzimanja imovine proistekle iz krivičnog dela u odnosu na te sankcije i mere s obzirom na evropske standarde koje smo dužni usvojiti i pronaći najbolje rešenje za naše društvene prilike. Oduzimanje imovine proistekle iz krivičnog dela svoju samostalnost zaslužuje najpre, zbog toga što usled specifičnosti koje je karakterišu često biva oprečna sa nekim od osnovnih ljudskih prava, te je kao takvu

\footnotetext{
${ }^{25} \mathrm{U}$ pravu sui generis je stručni izraz koji se koristi da identifikuje jedinstvenu nepripadajuću drugima pravnu kategorizaciju.
} 
treba vrlo oprezno primenjivati i u načelu usmeriti samo na područje najtežeg kriminaliteta, gde ona ostvaruje svoju punu svrhu. Sa druge strane, mera oduzimanja imovinske koristi potrebna je i pogodna za primenu u svim drugim slučajevima kada se ostvari imovinska korist izvršenjem krivičnog dela, bez obzira na težinu učinjenog krivičnog dela.

\section{Zaključak}

Mera oduzimanja imovine proistekle iz krivičnog dela javlja se kao neophodno sredstvo u rukama državne vlasti, da se narasli stepen prisustva organizovanog kriminala suzbije, kao i da se održi korak sa svim razvijenijim zemljama sveta koje već uveliko poznaju ovakav ili sličan mehanizam suzbijanja najtežih oblika kriminala. Izgradnja efikasnog sistema sprečavanja najtežih oblika kriminala podrazumeva najpre normativno i organizaciono dobro rešenje, a onda i rad na što intenzivnijem i efikasnijem sprovođenju donetih mera. Pitanje pravne prirode mere oduzimanja imovine proistekle iz krivičnog dela, iako nije pitanje od važnosti za njeno uspešno sprovođenje, nije malog značaja jer u zavisnosti od opredeljenja njene pravne prirode zavise i odgovori na neka pitanja koja se tiču njene praktične primene. Prvo i osnovno jeste pitanje dopuštene retroaktivne primene mere i zakona koji se na nju odnosi, a čiji odgovor proizilazi iz odgovora o njenoj pravnoj prirodi. Zatim, dalje se postavlja pitanje koliko je mera oduzimanja imovine mera koja je proizvod trenutnih problema sa kojima se naša država suočava, a koliko je ona sredstvo bez kojeg se krivičnopravni sistem sankcija i mera neće moći u budućnosti više zamisliti? Pitanje njenog položaja u okviru postojećeg sistema krivičnih sankcija i mera kao i analiza osobenosti koje je karakterišu pružili su nam adekvatnu smernicu za određenje pravne prirode mere oduzimanja imovine. lako joj se ne mogu osporiti određene primese kaznenog karaktera koje nosi ona se ne može posmatrati kao kazna, niti kao mera bezbednosti, jer je od njih dele značajne razlike.

Stavovi autora koji su se bavili temom pravne prirode oduzimanja imovine su različiti, a najviše je onih koji govoreći o njoj ne priznajući razlike koje postoje između njih, upućuju na već uvrežene stavove o pravnoj prirodi srodne ali ne iste mere, mere oduzimanja imovinske koristi. Nakon višegodišnje primene Zakona i mere oduzimanja imovine proistekle iz krivičnog dela, zaključujemo da je pitanje njene pravne prirode ne samo sporno nego još uvek nedovoljno obrađeno pitanje u našoj pravnoj nauci. Definisanje njene pravne prirode u ovom radu doprinosi boljem razumevanju relativno nove mere, njenom položaju u postojećem sistemu i otklanja veoma česte zabune i poteškoće u razdvajanju identiteta ovog instituta od njoj sličnih, a koje prate njeno postojanje. Na kraju izneti stav naglašava značaj naučne ekspertize posebne mere jer je prema stavu autora ona neizostavan deo svakog modernog krivičnog prava.

\section{Literatura}

[1] Gluščević, J. (2016): Upravljanje imovinom kriminalnog porekla i glavni uzročnici nedovoljne efikasnosti sistema upravljanja, Ekonomika, br. 3, Niš.

[2] Ignjatović, A. (2010): Zakon o oduzimanju imovine proistekle iz krivičnog dela, sa osvrtom na izmene Zakona o krivičnom postupku, Pravo Teorija i praksa, Beograd. 
[3] Ilić, G., Majić, M., Nikolić, B., Melilo, Đ., (2009): Komentar Zakona o oduzimanju imovine proistekle iz krivičnog dela, Misija OEBS, Beograd.

[4] llić, G. (2009): Pravna priroda trajnog oduzimanja imovine, Seminar o Zakonu o oduzimanju imovine proistekle iz krivičnog dela, Beograd.

[5] Ivičević Karas, E. (2011): Komentar Zakona o postupku oduzimanja imovinske koristi ostvarene kaznenim djelom i prekršajem, Narodne novine, Zagreb.

[6] Kambovski, V. (2006): Kazneno pravo opšt del, S-Štip, Skopje.

[7] Lajić, O. (2011): Institut oduzimanja imovinske koristi stečene krivičnim delom, Pravni fakultet Univerziteta u Novom Sadu, Novi Sad.

[8] Lazarević, Lj. (2006): Komentar Krivičnog Zakonika Republike Srbije: Savremena administracija, Beograd.

[9] Majić, M. (2010): Oduzimanje imovine proistekle iz krivičnog dela, Bilten Apelacionog suda u Beogradu, Broj I/2010, Beograd.

[10] Srzentić, N., Stajić, A., Lazarević, Lj. (1984): Krivično pravo SFRJ-opšti deo, Savremena administracija, Beograd.

[11] Škulić, M. (2010): Organizovani kriminalitet: Pravni fakultet Univerziteta u Beogradu, Beograd.

[12] Škulić, M. (2010): Kratki komentar osnovnih modifikacija krivičnog procesnog prava Srbije - izmene i dopune Zakonika o krivičnom postupku, odredbe Zakona o međunarodnoj pravnoj pomoći u krivičnim stvarima i odredbe Zakona o oduzimanju imovine proistekle iz krivičnog dela, Pravni portal, Smederevo.

[13] Tomić, Z. (1983): Pravna priroda mjere oduzimanja imovinske koristi pribavljene krivičnim delom, Godišnjak Pravnog fakulteta u Sarajevu, Sarajevo.

[14] Trešnjev, A. (2008): O radnoj verziji Nacrta Zakona o oduzimanju imovine proistekle iz krivičnog dela, Revija za bezbednost, Beograd.

[15] Vrhovšek, M. (2011): Šta još treba znati o oduzimanju imovine proistekle iz krivičnog dela, Sudska praksa: jugoslovensko stručno informativni časopis, br. 1/2, Beograd.

[16] Zakon o oduzimanju imovine proistekle iz krivičnog dela, Službeni glasnik RS, broj 97/08.

[17] Zakon o oduzimanju imovine proistekle iz krivičnog dela, SI. glasnik RS, br. 32/2013, 94/2016.

[18] Krivični zakonik, Službeni glasnik RS, br. 85/2005, 88/2005-ispr., 107/2005-ispr., 72/2009, 111/2009, 121/2012, 104/2013 , 108/2014 i 94/2016

[19] Ustav Republike Srbije, Službeni glasnik RS, br. 98/2006. 